\title{
Hunger and Its Associated Factors in an Urban Cluster in the Western Brazilian Amazon: A Population-Based Study
}

\section{Mayline Menezes da Mata}

Universidade Federal de São Paulo: Universidade Federal de Sao Paulo José Anael Neves

Universidade Federal de São Paulo: Universidade Federal de Sao Paulo

Maria Angélica Tavares de Medeiros ( $\nabla$ angelica.medeiros@unifesp.br)

Universidade Federal de São Paulo: Universidade Federal de Sao Paulo https://orcid.org/0000-00028982-7084

Research article

Keywords: Food and Nutritional Security, Nutrition Programs and Policies, Nutritional Epidemiology, Social Inequality, Nutritional Surveys.

Posted Date: July 13th, 2021

DOI: https://doi.org/10.21203/rs.3.rs-634658/v1

License: (c) (i) This work is licensed under a Creative Commons Attribution 4.0 International License. Read Full License 
Title: Hunger and its associated factors in an urban cluster in the Western Brazilian Amazon:

a population-based study

Short Title: Hunger and its associated factors in the Western Brazilian Amazon

Mayline Menezes da Mata

Programa de Pós-Graduação Alimentos, Nutrição e Saúde, Instituto Saúde e Sociedade, Universidade Federal de São Paulo Campus Baixada Santista, Rua Silva Jardim, $\mathrm{n}^{\circ}$ 136, Vila Mathias, CEP: 11015-020, Santos, São Paulo, Brasil.

Orcid ID: https://orcid.org/0000-0002-6142-5112

Phone: (+5511) 93234-2992

E-mail: mayline.menezes@unifesp.br

José Anael Neves

Programa de Pós-Graduação Interdisciplinar em Ciências da Saúde, Instituto Saúde e Sociedade, Universidade Federal de São Paulo Campus Baixada Santista, Rua Silva Jardim, no 136, Vila Mathias, CEP: 11015-020, Santos, São Paulo, Brasil.

Orcid ID: https://orcid.org/0000-0003-4139-4352

Phone: $(+5583)$ 99989-7025

E-mail: anael.neves@,unifesp.br

Maria Angélica Tavares de Medeiros

Departamento de Políticas Públicas e Saúde Coletiva, Instituto Saúde e Sociedade, Universidade Federal de São Paulo Campus Baixada Santista, Rua Silva Jardim, nº 136, Vila Mathias, CEP: 11015-020, Santos, São Paulo, Brasil.

Orcid ID: https://orcid.org/0000-0002-8982-7084

Phone: (+5513) 3229-0100

E-mail: angelica.medeiros@unifesp.br

Corresponding author: Maria Angélica Tavares de Medeiros.

E-mail: angelica.medeiros@unifesp.br

Departamento de Políticas Públicas e Saúde Coletiva, Instituto Saúde e Sociedade, Universidade Federal de São Paulo Campus Baixada Santista. Address: Rua Silva Jardim, nº 136, Vila Mathias, CEP: 11015-020, Santos, São Paulo, Brasil. 


\begin{abstract}
Background: Hunger affects millions of people worldwide. In the current pandemic scenario of COVID-19, Brazil experienced an epidemic peak of hunger, amplifying existing pre-pandemic vulnerabilities, mainly in the Northern Region of the Country. The aim of the present study was to investigate the prevalence of food insecurity and its associated factors in homes with children under five years of age in an urban cluster of a municipality of the Western Brazilian Amazon.
\end{abstract}

Methods: A household survey was conducted with a probabilistic sample of 557 children and their families. Food insecurity (FI) was determined using the Brazilian Food Insecurity Scale. Associations between variables were analyzed based on the prevalence ratio (PR) and respective 95\% confidence intervals (CI) calculated through multiple Poisson regression analysis. Variables with a $p$-value $<0.05$ after adjustments were considered significantly associated with the outcome.

Results: A high prevalence of food insecurity was found among the families in the study $(76.47 \%, \mathrm{PR}=1.90, \mathrm{CI}$ : 1.36-2.67, $p<0.001) ; 42.90 \%$ had moderate $(\mathrm{PR}=1.93, \mathrm{CI}: 1.31-2.83, p<0.01)$ and severe $(\mathrm{PR}=1.41, \mathrm{CI}: 1.10$ $1.83, p<0.02) \mathrm{FI}$, which was associated with low family income, participation in governmental income transfer programs, and heads of households with less than seven years of schooling. Moreover, substantial frequencies of height deficit and overweight were found among the children.

Conclusions: The high prevalence of hunger and food insecurity and its associated factors reflects the context of geographic isolation and social exclusion in which these families live, suggesting that a substantial portion of the population under five years of age had experienced episodes of hunger in the 90 days prior to the survey. The high prevalence of height deficit and overweight among the children reveals a scenario of epidemiological/nutritional polarization, requiring the formulation of specific public policies for this population.

Keywords: Food and Nutritional Security; Nutrition Programs and Policies: Nutritional Epidemiology; Social Inequality; Nutritional Surveys. 


\section{BACKGROUND}

Hunger and food insecurity (FI) affects billions of people around the world. In recent years, efforts have been made to reduce the occurrence of FI. According to international agencies [1], Brazil is one of the 13 Latin American countries that were able to achieve a significant reduction in rates of hunger, malnutrition, and undereating, in 2014.

However, hunger increased between 2015 and 2017, with more intense effects among populations with greater social vulnerability [2]. Due to its large size, Brazil still remains with deep social inequalities among the different geographic regions [3].

The Brazilian Northern Region has poor strategic development indicators, including a high rate of FI (57.0\%), which is the highest in the country [4] and is associated with sociodemographic, economic, and environmental factors as well as access to public services [3]. Such negative indicators are accentuated in municipalities that are distant from capital cities, which concentrate and monopolize supply systems and public services. As a result, more isolated municipalities suffer most from the effects of social disparities [5].

In the current pandemic scenario, due to the new SARS-CoV-2, the State of Amazonas, in the Northern Region, has experienced the hardest health crisis in its history. In May 2020, its capital, Manaus, reached the epidemic peak and, in October of the same year, the attack rate by antibodies detectable $(76 \%)$ exceeded the estimate for the state of São Paulo, in Southeastern (29\%) [6], the Brazilian state with the third highest population density in the country [7]. As a consequence, in January 2021, during the second Covid-19 wave [8], the Amazon Health System got into a collapse. The efforts to mitigate the spread of the epidemic in Amazonas were insufficient, which led to an increase in the mortality rate and in pre-existing vulnerabilities, with negative impacts to the social indicators all over the country [9].

At the present time, Brazil has experienced an epidemic peak of hunger, about 19.1 million Brazilians are in severe food insecurity (IAG), and the Northern Region is one of the most affected, with an index corresponding to $18.1 \%$ of households in IAG [10].

The municipality of Coari is located in the Western portion of the Brazilian Amazon Region and has the second highest gross domestic product in the state of Amazonas, due to the exploration of petroleum and natural gas. Nevertheless, Coari has a low human development index (0.586) [11] and the child mortality rate is 18.2 per every thousand live births [12], which demonstrates the precarious living conditions and health of the population. In the context of social inequities, it is essential to gain knowledge on the food and nutritional situation of homes in geographically isolated regions, access to which is only possible by water or air, which creates an obstacle for the execution of national surveys. The scarcity of scientific information on health, diet, 
and nutrition in the countryside of the state of Amazonas hinders planning and decision making with regards to public policies to meet local needs.

The aim of the present study was to investigate the prevalence of food insecurity and its associated factors in homes with children under five years of age in a municipality of the Western Amazon Region of Brazil.

\section{METHODS}

Design

A household survey was conducted in homes with children under five years of age in an urban cluster of the municipality of Coari in the state of Amazonas, Brazil, in the period between March and July 2018.

\section{Study setting}

The municipality of Coari is located on the Urucu River of the Solimões River basin in the Western portion of the Amazon Region in Brazil. The city has an area of 58,17.27 km², is located $363 \mathrm{~km}$ from the state capital (Manaus), and is inaccessible by land. The estimated population, in 2020, was 85,910 residents. In 2010 this population corresponded to $75,965,49,651$ in urban clusters and 26,314 in rural areas, with a demographic density of 1.31 inhabitants per $\mathrm{km}^{2}$ [7]. With a view to international comparability, it was adopted the classification of urban agglomeration, for the study area in the municipality of Coari [13].

\section{Sample}

Probabilistic sampling was performed in three stages: Forty-nine census sectors, streets, and homes with at least one resident under five years of age were selected; a random drawing was performed, when necessary. The sample size was calculated considering a population of 5,792 children between 0 and 4 years of age in urban areas of the municipality [7], a 36.1\% rate of FI in the Northern Region of the country in 2013 [14], a $95 \%$ confidence level, and $4 \%$ absolute error. For the final same, an adjustment was performed for a finite population, assuming a $10 \%$ dropout rate, which resulted in a minimum $n$ of 557 children.

\section{Instrument and data collection}

A questionnaire was created with closed-ended questions organized into the following components: identification/location of home; characterization of residents; characteristic of home; participation in income transfer programs; healthcare services; characteristics of the head of the family; characteristics of mother and child; and food (in)security. Interviews were held with the person in charge of the meals in the home. Twentytwo trained interviewers conducted the interviews, working in pairs. 
Food (in)security was assessed using the Brazilian Food Insecurity Scale [15], which enables measuring the perception of families regarding access to foods. The scale is composed of 14 items addressing the food situation experienced in the 90 days prior to the interview.

For the assessment of nutritional status, anthropometric measures were taken in duplicate using standard procedures and calibrated equipment. The following indices were considered: weight/age (W/A), height/age (H/A), weight/height $(\mathrm{W} / \mathrm{H})$, and body mass index/age (BMI/I). The indices were expressed as zscore using the growth curves of the World Health Organization as reference [16].

The following variables of interest were used in the data analysis: demographic characteristics of the head of the household and children; 1. Participation in governmental income transfer program; 2. Characteristics of the home: number of rooms and existence of durable consumer goods; 3 . Occupation of head of family; 4. Access to public services (water supply, garbage collection, electricity, and sewage system); 5. Economic class according to the Brazilian Economic Classification Criteria [17], grouped into the following classes: A; B1 and B2; C1 and C2; D and E; 6. Child's nutritional status; 7. Food (in) security.

\section{Data analysis}

The data were double entered and inconsistencies were verified with the aid of Epi Info®, version 7.0. Stata ${ }^{\circledR}$ version 13.0. (College Station, TX, USA) and WHO Anthro® (2005) version 3.2.2 (11) were used for the statistical analyses. Descriptive statistics were performed, with the calculation of absolute and relative frequencies for qualitative variables and measures of central tendency and dispersion for quantitative variables. Multiple Poisson regression analysis was performed to determine possible statistically significant associations between the response variable (moderate to severe food insecurity [MSFI]) and the predictors (co-variables). Prevalence ratios (PR) and respective 95\% confidence intervals $(\mathrm{CI})$ were estimated in unadjusted $(p<0.20)$ and adjusted $(p<0.05)$ models. All variables with a $p$-value $<0.20$ in the univariate analysis were incorporated into the multiple regression model using the stepwise forward procedure and all those with a $p$-value $<0.05$ after the adjustments remained in the final model as significantly associated with the outcome.

\section{Ethical aspects}

This study received approval from the institutional review board of Universidade Federal de São Paulo (certificate number: 83010018.8.0000.5505). Statements of informed consent and assessment (for mothers younger than 19 years of age) were read by the interviewers and presented for signatures. For those who reported having difficulties or did not know how to sign their names, an ink blotter was used to collect the fingerprint. 


\section{RESULTS}

Among the 557 children under five years of age, $76.47 \%$ (95\% CI: 72.76\%-79.82\%) had some degree of FI. Among these children, 33.58\% (95\% CI: 29.75\%-37.61\%) had mild FI, $17.42 \%$ (95\% CI: $14.47 \%$ 20.80\%) had moderate FI, and 25.49 (95\% CI: 22.03\%-29.29\%) had severe FI, which means hunger.

Data on the sociodemographic characterization of the heads of households are displayed in Table 1. Among the 557 homes visited, 32.14\% were headed by grandparents, $60.32 \%$ were male, and mean age was 40 years (standard deviation [SD]: 14.41). The majority had self-declared brown skin color (71.81\%), a spouse/partner (66.97\%), up to seven years of schooling (45.24\%), no formal employment (75.58\%), and earned up to the monthly minimum wage (67.50\%), which was R\$ 954 in 2018 (reference year of the study) [18].

A total of $42.73 \%$ of the homes were made of wood and had electricity (98.38\%), but only $21.90 \%$ had piped water from the public water supply, leading to a frequent lack of water (62.66\%). Regarding the destination of domestic sewage, $45.06 \%$ of the residents dumped it in the open air and rivers/creeks adjacent to the home. A total of $50.81 \%$ of the homes were located on unpaved streets. The homes had an average of six residents. Economic classes D and E predominated $(72.17 \%)$ and $78.28 \%$ of the interviewees reported participating in governmental income transfer programs.

Among the 557 children, $53.86 \%$ were boys, $79.53 \%$ had brown skin color, and mean age was 21 months (SD: 15.42). The prevalence of height for age deficit was 23.7\% (95\% CI: 20.1\%-27.3\%, SD: 1.39$)$ and the prevalence of overweight was $16.3 \%$ (95\% CI: $13.2 \%-19.5 \%$, SD: 1.22$)$.

In the unadjusted Poisson regression analysis, moderate to severe food insecurity (MSFI) was associated with type of housing, number of residents, public garbage collection service, participant in governmental income transfer programs, and sociodemographic characteristics of the head of the family (Table 2).

In the adjusted analysis, the following variables remained associated with MSFI: income, access to a governmental program, and schooling of the head to the family. Homes earning less than the monthly minimum wage were 1.90-fold more likely to experience episodes of MSFI compared to those that earned more than the monthly minimum wage $(\mathrm{PR}=1.90 ; 95 \% \mathrm{CI}: 1.36-2.67 ; p<0.001)$. Families participating in governmental income transfer programs were 1.93 -fold more likely to experience situations of MSFI, compared to those who did not participate in such programs $(\mathrm{PR}=1.93 ; 95 \% \mathrm{CI}: 1.31-2.83 ; p<0.01)$. Families in which the head of the household had a low level of schooling ( $\leq 7$ years of study) were 1.41-fold more likely to experience MSFI, compared to those in which the head of the household had a higher level of schooling (PR $=1.41 ; 95 \% \mathrm{CI}: 1.10$ $1.83 ; p<0.02)$. 
Figure 1 shows the conceptual model created to identify social determinants of IA and potential consequences in this population.

\section{DISCUSSION}

A high rate of food insecurity was found in homes with children under five years of age, which was was more than double the prevalence reported for Brazil as a whole (36.7\%) [4]. Severe IA affected $25.49 \%$ of the families interviewed, surpassing the prevalence reported for the Northern Region of the country $(10.2 \%)$ and suggesting that a significant portion of the population under five years of age had suffered episodes of hunger in the 90 days prior to the interview. These results overcome, as well, data from a recent Brazilian Report, which points to the Northern Region as the most affected by hunger in the country [10]. In the same direction, the index of severe FI found in the present study exceeds the high prevalence identified in children from Ethiopia, a country that still lives with hunger and malnutrition in urban environments [19].

Among the characteristics analyzed, a low income, participation in governmental income transfer programs and schooling of the head of the household were associated with moderate to severe food insecurity (MSFI). These findings are compatible with data described by other authors [20].

An income below the monthly minimum wage (R\$ 954) was the factor most associated with MSFI, implying difficulty in gaining access to food. Mean household income per capita in the municipality studied was $\mathrm{R} \$ 347.20$, with $62.36 \%$ of individuals earning less than $\mathrm{R} \$ 140$, which classifies these individuals as poor to extremely poor (IBGE 2010). This corresponds to half of the lowest mean per capita (R\$ 605) recorded for Brazil in 2018, referred to the state of Maranhão in the Northeastern Region of the country [21]. Thus, the present results reaffirm findings in studies with a national scope, which state that a lower monthly household income is associated with a higher proportion of homes with FI, especially MSFI [20].

In the analysis of participation in governmental income transfer programs, which was also associated with MSFI, such programs are suggested to have achieved public priorities [22, 23]. Given the large portion of the interviewees in the present study who reported monetary transfers from the Programa Bolsa Familia (Family Allowance Program) as the only source of income, FI would likely be greater without such programs.

Access to food is hindered by low income. Therefore, the association between MSFI and participation in programs such as the Programa Bolsa Família (Family Allowance Program) may be explained by the extreme poverty to which the heads of the households are submitted [24]. Although the trajectory of this program is related to a reduction in social inequalities in Brazil, structural disparities persist in the territories (regions, states, and municipalities). Income transfer alone is insufficient to interrupt poverty; in the sphere of public policies, it 
is also necessary to qualify services related to cross-compliance and expand intersectoral interventions targeting vulnerable populations $[23,25,26]$.

Low schooling, which was also associated with MSFI in the present study, makes it difficult to enter the formal job market, implying an increase in informal ("under-the-table") work and low pay, constituting a marker of inequity that favors the perpetuation of food insecurity [20]. Regarding claims that the Programa Bolsa Família (Family Allowance Program) rectifies late enrollment, school attendance, and truancy rates of children from poorer families, there is evidence that these children leave school prematurely [27]. It should be stressed that an increase in the schooling of the population is a basic requirement for the interruption of the generational cycle of poverty [28].

As an aggravating factor of MSFI, a frequent lack of water was found in the homes due to low coverage by the public water supply [7] and the discarding of domestic sewage in the open air, as well as in rivers and creeks adjacent to the homes. Although not part of the final statistical model, these aspects aggregate elements for the analysis of the vulnerability of the population. Despite the fact that Brazil is recognized for its considerable freshwater supply, part of the population does not have sufficient access to this water, especially in the Northern and Northeastern Regions of the country [29]. Moreover, insufficient basic sanitation in the municipality of Coari, due to the natural dynamics of the waters (ebb and flow), could contribute to the maintenance or increase in child mortality rates, as limited access to water, sanitation, and adequate hygiene are among the determinants [30].

Height deficit was not associated with MSFI. Nonetheless, the high prevalence encountered (23.7\%) is approximately double the average for the Northern Region (14.7\%) (MS 2009) [31], demonstrating a situation of chronic malnutrition. This result is similar to the prevalence described in one of the least developed municipalities of Brazil, which is also located in the Western Amazon Region (35.8\%); the prevalence of height deficit was associated with geographic isolation, social inequalities and difficulties in gaining access to services in the Northern Region [32]. Regional data reveal that height deficit in the population is the consequence of prolonged exposure to hunger and nutritional deficiencies [33], as children in Northern Brazil are less likely to have access to a diversified, healthy diet, in comparison to those in other regions of the country [34]. Despite the reduction in chronic malnutrition on the national level, regional inequities persist, which contribute to the high rates of growth deficit in childhood in the Northern Region [35].

Along with the persistent problem of childhood malnutrition in the municipality, a substantial portion of the children studied were overweight, surpassing the global prevalence estimated for children and adolescents, according to a study reporting a growing trend of excess weight in developing countries from $8.1 \%$ to $12.9 \%$ in 
the male sex and from $8.4 \%$ to $13.4 \%$ in the female sex. These rates are higher in developed countries $(23.8 \%$ in the male sex and $22.6 \%$ in the female sex) [36]. Children from families with FI in developed countries also have a greater likelihood of poorer health since birth and a worse perception of their health on the part of parents [37].

No association between MSFI and overweight was found in the present study, which is similar to findings in an investigation involving data from the Brazilian Demographics and Health Survey [31, 38]. However, Tarasuk et al. [39] suggest that MSFI may be a conditioning factor for an increase in morbidity rates and hospitalizations. Likewise, Gomes et al. [40] found that nutritional risk among individuals with chronic morbidities is greater among those with MSFI. Moreover, excess weight in childhood is a risk factor for obesity and chronic noncommunicable diseases in adulthood [41].

The context of inequities in the families that participated in the present study was characterized by the low economic status and schooling of the heads of the households, massive participation in governmental income transfer programs, as well as inadequate housing and sanitation, painting a picture of intense social disparities.

MSFI and associated factors reveal the precariousness of economic development and public policies in areas distant from large metropolises. The geographic isolation of the region is a recurrent justification for the historical lack of public policies directed at this population. As a result, social exclusion deepens, which is evidenced in lower income strata with lower levels of schooling deprived of access to the job market and public services [42]. The intensification of these social disparities, mainly in territories historically marked by social inequalities, is among the impacts of the pandemic by the new SARS-CoV-2. Thus, it is suggested that moderate and severe FI are even higher currently [43]. The State should play a central role in the fulfillment of basic rights that favor the social inclusion of the population and the consequent overcoming of socioeconomic inequalities and food insecurity. Likewise, social control agencies perform a role in monitoring this process. However, Brazil is currently passing through a period marked by austerity policies, which weaken existing social protection policies [44]. It is, therefore, necessary to place food insecurity and the human right to adequate, healthy food on the agenda of different governmental courts of Brazil, for the enforcement of public policies for combating hunger and poverty [23].

A limitation of the present study was the impossibility of including rural areas in the survey, due to budgetary and logistic deficiencies. Otherwise, the research's innovativeness resides in the fact that it is an unprecedented population-based inquiry, addressing a remote municipality in the Western portion of the Brazilian Amazon Region which is not covered in national surveys. Therefore, the present investigation fills a gap in knowledge on this issue regarding municipalities in the countryside of Northern Brazil. 


\section{CONCLUSIONS}

The high prevalence of hunger and food insecurity, associated with low income, low schooling of the heads of households and participation in governmental income transfer programs translates to the structural vulnerability of these families. Moreover, the substantial height deficit and simultaneous prevalence of overweight among the children points to epidemiological-nutritional polarization in this municipality of the Brazilian Western Amazon. Geographic isolation and limited access to public services are suggested to exert a negative impact on social inclusion in this population, contributing to the perpetuation of inequalities.

\section{ABBREVIATIONS}

Food insecurity (FI); Weight/age (W/A); Height/age (H/A); Weight/height (W/H); Body mass index/age (BMI/I); Moderate to severe food insecurity (MSFI); Prevalence ratios (PR); Confidence intervals (CI); Standard deviation $(\mathrm{SD})$.

\section{DECLARATIONS}

Ethics approval and consent to participate: This study was conducted according to the guidelines laid down in the Declaration of Helsinki and all procedures involving research study participants were approved by the Universidade Federal de São Paulo (certificate number: 83010018.8.0000.5505).

Consent for publication: The authors declare that the free and informed consent terms were signed by all the participants in this research..

Availability of data and materials: The datasets used and/or analysed during the current study are available from the corresponding author on reasonable request.

Competing interests: The authors declare that they have no conflict of interest.

Funding: The authors declare that this study received no funding.

Authors' contributions: Mayline Menezes da Mata participated in the conception and design of the study, analysis and discussion of the results, writing and critical review of the manuscript; José Anael Neves participated in the discussion of the results, writing and critical review of the manuscript; Maria Angélica Tavares de Medeiros participated in the conception and design of the study, discussion of the results, writing and critical review of the manuscript for intellectual content. All authors approved the final version of the manuscript. 
Acknowledgements: To the families who participated in the study.

\section{Authors' information (optional):}

Mayline Menezes da Mata - Assistant Professor at the Universidade Federal do Amazonas (UFAM), PhD student in Nutrition and Master's degree in Health Sciences at the Universidade Federal de São Paulo (UNIFESP), Brazil. She is currently conducting a research related to living conditions, health, nutrition, and food security in vulnerable populations in the Western Brazilian Amazon, Brazil and integrates the research group Laboratory of Food and Nutritional Security and Public Policies (UNIFESP/CNPq), coordinated by Professor Maria Angélica Tavares de Medeiros .

José Anael Neves - Adjunct Professor at the Universidade Metropolitana de Santos, PhD and Master's degree in Health Sciences at the Universidade Federal de São Paulo Campus Baixada Santista Santos, São Paulo, Brazil. He is a member of the research group Laboratory of Food and Nutritional Security and Public Policies (UNIFESP/CNPq), coordinated by Professor Maria Angélica Tavares de Medeiros. Interested in research in the area of Food and nutrition programmes and policies and nutrition in public health.

Maria Angélica Tavares de Medeiros - Associate Professor at the Universidade Federal de São Paulo Campus Baixada Santista, Santos, São Paulo, Brasil. Advisor of the Graduate Programs in Nutrition and Interdisciplinary in Health Sciences. PhD in Collective Health and Master's degree in Sociology by the Universidade Federal de Campinas (UNICAMP), Campinas, São Paulo. Sanitarian nutritionist at the Universidade Federal da Paraíba (UFPB). Coordinator of the research group Laboratory of Food and Nutritional Security and Public Policies (Conselho Nacional de Desenvolvimento Científico e Tecnológico, CNPq). Research activities are centered in the following issues: Collective health and food and nutrition security and policies in vulnerable populations.

\section{REFERENCES}

1. FAO, IFAD, UNICEF, WFP and WHO. (2015). The state of food insecurity in the World 2015. Meeting the 2015 international hunger targets: taking stock of uneven progress. Rome: Food and Agriculture Organization of the United Nations. http://www.fao.org/policy-support/tools-andpublications/resources-details/en/c/469455/. Accessed 20 Jan 2021.

2. Sousa LRM, Segall-Corrêa AM, Ville AS, Melgar-Quiñonez H. Food security status in times of financial and political crisis in Brazil. Cad Saúde Pública. 2019; doi.org/10.1590/0102-311x00084118. 
3. Santos TG, Silveira JAC, Longo-Silva G, Ramires EKNM, Menezes RCE. Trends and factors associated with food insecurity in Brazil: the National Household Sample Survey, 2004, 2009, and 2013. Cad Saúde Pública. 2018; doi.org/10.1590/0102-311x00066917.

4. IBGE. (2020). Pesquisa de orçamentos familiares 2017-2018: análise da segurança alimentar no Brasil. Rio de Janeiro: Instituto Brasileiro de Geografia e Estatística. Available at: https://biblioteca.ibge.gov.br/visualizacao/livros/liv101749.pdf. Accessed Out 2020.

5. Garnelo L, Sousa ABL, Silva CO. Health regionalization in Amazonas: progress and challenges. Ciên Saúde Colet. 2017; doi.org/10.1590/1413-81232017224.27082016.

6. Buss LF, Prete CA, Abrahim CMM, Mendrone AJr, Salomon T, Almeida-Neto C, et al.Three-quarters attack rate of SARS-CoV-2 in the Brazilian Amazon during a largely unmitigated epidemic. Science. 2020; 2020; doi.org/10.1126/science.abe9728.

7. IBGE. Sinopse do censo demográfico de 2010. Available at: https://censo2010.ibge.gov.br/sinopse/index.php?uf=13\&dados= (2010). Accessed 12 Jan 2018.

8. Sabino EC, Buss LF, Carvalho MPS, Prete Jr CA, Crispim MAE, Fraiji NA, et al. Resurgence of COVID-19 in Manaus, Brazil, despite high seroprevalence. The Lancet. 2021; doi.org/10.1016/ S01406736(21)00183-5.

9. He D, Artzy-Randrup Y, Musa SS, Stone L. The unexpected dynamics of COVID-19 in Manaus, Brazil: Herd immunity versus interventions. The Preprint Server for Health Sciences. 2021; https://doi.org/10.1101/2021.02.18.21251809.

10. Rede Brasileira de Pesquisa em Soberania e Segurança Alimentar e Nutricional. Inquérito Nacional sobre Insegurança Alimentar no Contexto da Pandemia da COVID-19 no Brasil. http://olheparaafome.com.br (2021). Accessed 23 april 2021.

11. PNUD, IPEA and FJP. Atlas of Human Development in Brazil: profile socioeconomic of municipalities of Brazil: Coari, Am. Brasília, DF: PNUD. http://atlasbrasil.org.br/2013/en/perfil_m/coari_am (2013). Accessed 20 Jan 2018.

12. Ministério da Saúde. BR Sistema de Informação sobre Mortalidade DATASUS. Available at: http://www2.datasus.gov.br/DATASUS/index.php?area=0205\&id=6938\&VObj=http://tabnet.datasus.g ov.br/cgi/deftohtm.exe?sim/cnv/inf10 (2021). Accessed 15 Fev 2021.

13. Bureau USC. Census Urban and Rural Classification and Urban Area Criteria. http://www.census.gov/geo/www/ua/2010urbanruralclass.html (2010). Accessed 20 April 2021. 
14. IBGE. Pesquisa Nacional por Amostra de Domicílios: segurança alimentar 2013. Rio de Janeiro: $\begin{array}{lllll}\text { Instituto } & \text { Brasileiro } & \text { Geografia } & \text { e } & \text { Estatística; }\end{array}$ https://biblioteca.ibge.gov.br/visualizacao/periodicos/59/pnad_2013_v33 br.pdf (2014). Accessed 25 Jan 2018.

15. Segall-Corrêa, AM, Marin-LeónL, Melgar-QuiñonezH, \& Pérez-EscamillaR. . Refinement of the Brazilian Household Food Insecurity Measurement Scale: Recommendation for a 14-item EBIA. Rev Nutr. 2014; https://doi.org/10.1590/1415-52732014000200010.

16. WHO. Anthro 2005, Beta version Feb 17th, 2006: Software for assessing growth and development of the world's children. Geneva: World Health Organization; 2006. https://www.who.int/childgrowth/software/en/ (2006). Accessed 12 Set 2018.

17. ABEP. Critérios de Classificação Econômica Brasil. In: Alterações na Aplicação do Critério Brasil. http://www.abep.org/criterioBr/01 cceb 2019.pdf (2019). Accessed 18 Fev 2019.

18. Brasil. Decreto $n^{\circ} 9.255$, de 29 de dezembro de 2017. Regulamenta a Lei $n^{\circ} 13.152$, de 29 de julho de 2015, que dispõe sobre o valor do salário mínimo e a sua política de valorização de longo prazo. Diário Oficial da União 28 dez de 2017.

19. Dinku AM, Mekonnen TC, Adilu GS. Child dietary diversity and food (in)security as a potential correlate of child anthropometric indices in the context of urban food system in the cases of northcentral Ethiopia. Journal of Health, Population and Nutrition. 2020; doi.org/10.1186/s41043-020-00219-6.

20. Bezerra TA, OlindaRA, Pedraza DF. Food insecurity in Brazil in accordance with different sociodemographic scenarios. Ciên Saúde Colet. 2017; doi.org/10.1590/1413-81232017222.19952015.

21. IBGE. Rendimento domiciliar 2018. https://www.ibge.gov.br/busca.html?searchword=pnad20contínua\&searchphrase=all (2019). Accessed 15 Mai 2019.

22. Martins APB, Monteiro CA. Impact of the Bolsa Família program on food availability of low-income Brazilian families: a quasi-experimental study. BMC Public Health; 2016. doi.org/10.1186/s12889-016$3486-\mathrm{y}$

23. Neves JA, VasconcelosFAG, Machado ML, RecineE, Garcia GS, Medeiros MAT. The Brazilian cash transfer program (Bolsa Família): A tool for reducing inequalities and achieving social rights in Brazil. Global Public Health. 2020; doi/abs/10.1080/17441692.2020.1850828?journalCode=rgph20.

24. Anschau FR, Matsuo T, Segall-Corrêa AM. Food insecurity among recipients of government assistance. Rev Nutr. 2012; doi.org/10.1590/S1415-52732012000200001. 
25. Neder H, Alves Filho N, Souza $\mathrm{S}$. Acesso à renda e inflação de preços de alimentos no Brasil: análise dos efeitos do programa Bolsa Família. Rev. Econ. Sociol. 2015; doi.org/10.1590/1234-56781806$\underline{9479005301003 .}$.

26. Alves H, Escore 1S. Social exclusion and health inequity: a case study based on a cash distribution program (BolsaFamília) in Brazil. Rev Panam Salud Publica. 2013;34(4):429-436.

27. Ford K, Lourenço B, Cobayashi F, Cardoso M. Health outcomes of the Bolsa Família program among Brazilian Amazonian children. Rev Saúde Pública. 2020; doi.org/10.11606/s15188787.2020054001519.

28. Silva MMS. Conditional cash transfers and improved education quality: a political search for the policy link. Int J Educ Dev. 2015; doi.org/10.1016/j.ijedudev.2015.09.003.

29. Lima JA, Dambros MVR, Antonio MAPM, Janzen JG. Potential for potable water savings by using rainwater: an analysis over 40 cities in Amazon. Eng Sanit Ambient. 2011; doi.org/10.1590/S1413$\underline{41522011000300012 .}$.

30. Reiner JrRC, Wiens KE, Deshpande A, Baumann MM, Lindstedt PA, Blacker BF, et al. . Mapping geographical inequalities in childhood diarrhoealmorbidity and mortality in low-income and middleincomecountries, 2000-17: analysis for the Global Burden of Disease Study 2017. Lancet. 2020; doi.org/10.1016/ S0140-6736(20)30114-8.

31. Ministério da Saúde. BR National Survey on Demography and Health of Women and Children - PNDS 2006: dimensions of reproduction and child health. Brasília: Ministério da Saúde, 2009. Available at: http://bvsms.saude.gov.br/bvs/publicacoes/pnds crianca mulher.pdf (2009). Accessed Out 2020.

32. Araújo TS, Oliveira CSM, Muniz PT, Silva-Nunes M, Cardoso MA. Child undernutrition in one of the cities with greater nutritional risk in Brazil: population based study in the Western Brazilian Amazon. Rev Bras Epidemiol. 2016; doi.org/10.18316/sdh .v8i1.5752.

33. Alencar FH, Yuyama LKO, Varejão MJC, Marinho HA. Alimentary insecurity determinants and consequences at Amazonas: ecosystems influences. Acta Amaz, 2007; doi.org/10.1590/S0044$\underline{59672007000300012 .}$.

34. Bortolini GA, Vitolo MR, Gubert MB, Santos LMP. Iniquidades sociais influenciam a qualidade e a diversidade da dieta de crianças brasileiras de 6 a 36 meses. Cad Saúde Pública. 2015, doi.org/10.1590/0102-311X00153414. 
35. Corrêa EM, Vessoni AT, Jaime PC. Magnitude da Desnutrição Infantil na Região Norte Brasileira: uma Revisão de Escopo. Revista Saúde e Desenvolvimento Humano. 2020; doi.org/10.18316/sdh .$v 8 \mathrm{i} 1.5752$.

36. Ng M, Fleming T, RobinsonM, Thomson B, Graetz N, Margono C, et al. Global, regional, and national prevalence of overweight and obesity in children and adults during 1980-2013: a systematic analysis for the Global Burden of Disease Study 2013. Lancet. 2014; doi.org/10.1016/S0140-6736(14)60460-8.

37. Zaçe D, Di Pietro ML, Reali L, Waure C, Ricciardi W. Prevalence, socio-economic predictors and health correlates of food insecurity among Italian children- findings from a cross-sectional study. Food Security. 2021; doi.org/10.1007/s12571-020-01111-1.

38. Gubert MB, Spaniol AM, Bortolini GA, Peréz-Escamilla R. Household food insecurity, nutritional status and morbidity in Brazilian children. Public Health Nutr. 2016; doi: $10.1017 / \mathrm{S} 1368980016000239$.

39. Tarasuk V, Cheng J, Oliveira C, Dachner N, Gundersen C, Kurdyak P.. Association between household food insecurity and annual health care costs. CMAJ. 2015; doi: 10.1503/cmaj.150234.

40. Gomes NIG, Vianna RPT, Medeiros ARC, Lima RLFC. Nutritional risk, food insecurity and quality of life in people living with HIV/AIDS in Paraíba, Brazil. Food Security. 2020; doi:10.1007/s12571-020$\underline{01102-2 .}$

41. Black RE, Victora CG, Walker SP, Bhutta ZA, Christian P, Onis M. Maternal and child undernutrition and overweight in low-income and middle-income countries. Lancet. 2013; doi.org/10.1016/S0140$\underline{6736(13) 60937-X .}$

42. Garnelo L. Especificidades e desafios das políticas públicas de saúde na Amazônia. Cad Saúde Pública. 2019; doi.org/10.1590/0102-311x00220519.

43. Rocha R, Atun R, Massuda A, Rache B, Spinola P, Nunes L, et al. Effect of socioeconomic inequalities and vulnerabilities on health-system preparedness and response to COVID-19 in Brazil: a comprehensive analysis. The Lancet Global Health. 2021; doi.org/10.1016/S2214-109X(21)00081-4.

44. Vasconcelos FAG, Machado ML, Medeiros MAT, Neves JA, Recine E, Pasquim EM. Public policies of food and nutrition in Brazil: from Lula to Temer. Rev Nutr. 2019; doi.org/10.1590/1678$\underline{9865201932 \mathrm{e} 180161 .}$. 


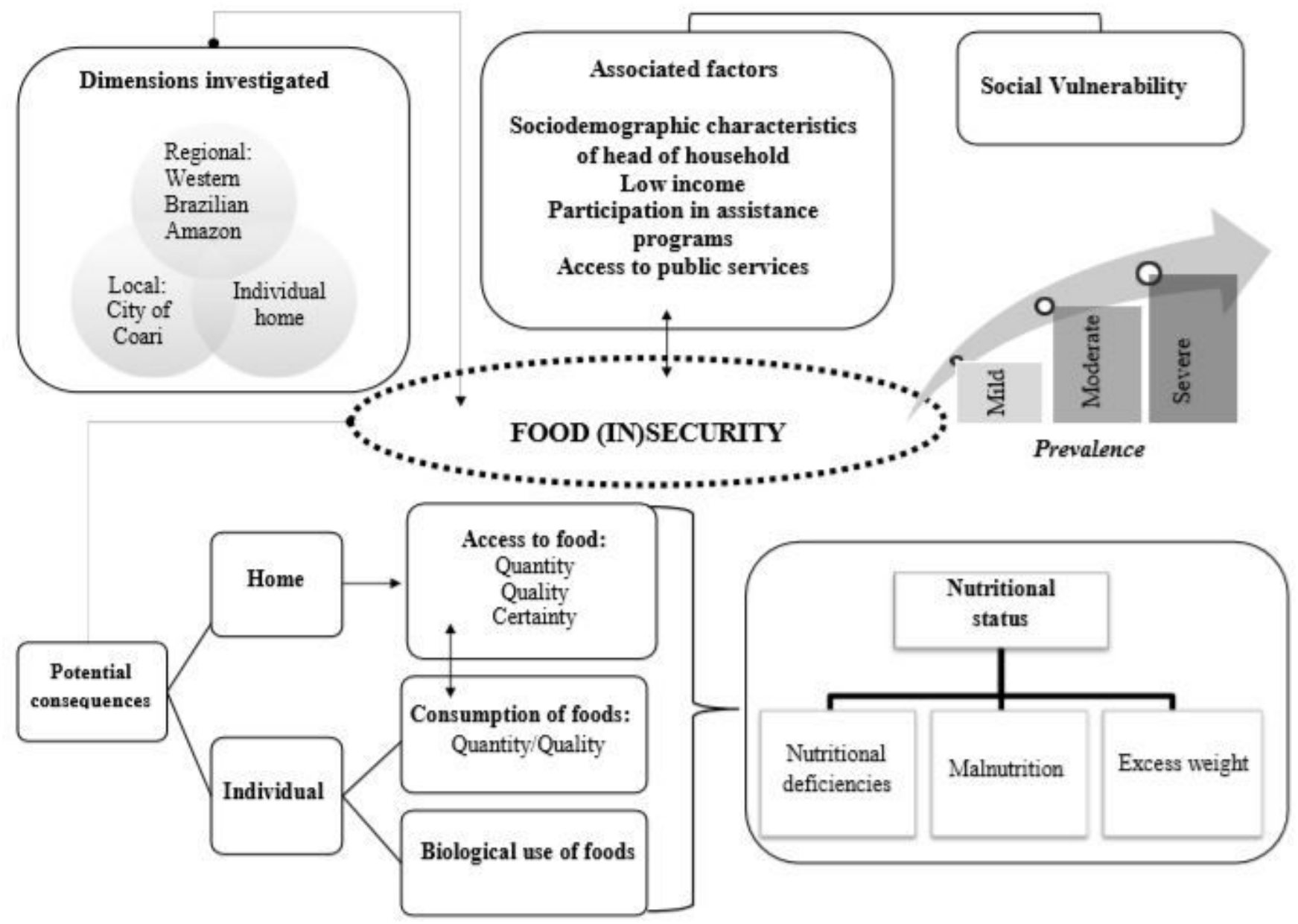

Figure 1

Conceptual model of determinants and potential consequences of food insecurity in a population of the Western Brazilian Amazon, 2019. Source: The authors.

\section{Supplementary Files}

This is a list of supplementary files associated with this preprint. Click to download.

- Table1HealthPopulationandNutrition.pdf

- STROBEchecklistcrosssectional.pdf

- Table2JHealthPopulNutr.pdf 